\title{
Analisis Struktur Baja Tahan Gempa dengan Sistem SRPMK (Struktur Rangka Pemikul Momen Khusus] Berdasarkan SกI 1729:2015 dan SกI 1726:2012
}

\author{
M.Y. Zachari ${ }^{\mathrm{a}}$ dan G. Turuallo ${ }^{\mathrm{b} *}$ \\ ${ }^{a}$ Alumni Jurusan Teknik Sipil Universitas Tadulako, Jl. Soekarno Hatta Km. 9 Palu 94118, Indonesia \\ bJurusan Teknik Sipil Universitas Tadulako, Jl. Soekarno Hatta Km. 9 Palu 94118, Indonesia \\ ${ }^{*}$ Corresponding author's e-mail: turuallo@yahoo.co.uk
}

Received: 12 August 2020; revised: 22 August 2020; accepted: 23 August 2020

\begin{abstract}
The selection of material is one of the important aspects used to design a building as it is known that every type of material has a different characteristic. The steel material used as the main component of building structure because of its ductility is more than another material which is the main criterion to design an earthquake resistance building. In this paper, an earthquake steel resistant structure building will be design. This building structure will consist of a five-story office with a regular structure configuration. A special moment frame (SMF) used as the resisting structure system of the earthquake loads as the amount of its load is analyzed using the spectrum response method. The steel material used is type of A36 (fy $=250 \mathrm{MPa}$; fu $=400 \mathrm{MPa}$ ), concrete used f'c $=30 \mathrm{MPa}$. The design process then produces an earthquake steel resistant structure building, which satisfies the requirement of story drift with a maximum number of story drift occurred in the 2nd story which is $93.5 \mathrm{~mm}$ less than allowed story drift that is $95 \mathrm{~mm}$. A structure element dimension used is a beam with a profile of $\mathrm{W} 16 \times 7 \times 40$ for every level in the $\mathrm{X}$-axis direction, and the beam with a profile is $\mathrm{W} 14 \times 6.75 \times 38$ for every level in $\mathrm{Y}$-axis direction, $12 \mathrm{~cm}$ thick plates and column with a profile $\mathrm{W} 14 \times 16 \times 211$ is regularly used to every level.
\end{abstract}

Keywords: ductility, earthquake resistance building, special moment frame and spectrum response method.

Abstrak: Pemilihan material merupakan salah satu aspek penting yang digunakan untuk mendesain suatu bangunan karena diketahui setiap material memiliki karakteristik yang berbeda-beda. Tulisan ini bertujuan untuk memberi gambaran bagaimana mendesain bangunan rangka baja berdasarkan sistim rangka pemikul momen khusus (SRPMK). Material baja digunakan sebagai komponen utama struktur gedung karena lebih daktail dari material lain yang mana menjadi kriteria utama dalam mendesain gedung tahan gempa. Struktur gedung ini merupakan gedung perkantoran yang terdiri dari lima lantai dengan konfigurasi struktur yang teratur. Sistim rangka pemikul momen khusus (SRPMK) yang digunakan sebagai sistem struktur penahan beban gempa yang besar bebannya dianalisis dengan menggunakan metode spektrum respon. Material baja yang digunakan adalah tipe A36 (fy $=250 \mathrm{MPa} ; \mathrm{fu}=400 \mathrm{MPa}$ ), beton yang digunakan $\mathrm{f}^{\prime} \mathrm{c}=30$ $\mathrm{MPa}$. Hasil perancangan menghasilkan bangunan struktur baja tahan gempa yang memenuhi persyaratan drift lantai dengan jumlah drift lantai maksimum yang terjadi pada lantai 2 yaitu $93,5 \mathrm{~mm}$ lebih kecil dari simpangan yang diperbolehkan yaitu $95 \mathrm{~mm}$. Dimensi elemen struktur yang digunakan adalah balok dengan profil Wx16x7x40 untuk setiap level pada arah sumbu-X, dan balok dengan profil adalah Wx14x6,75x38 untuk setiap level pada arah sumbu-Y, tebal pelat $12 \mathrm{~cm}$ dan kolom dengan a profil W14x16x211 secara teratur digunakan untuk setiap level.

Kata kunci: daktilitas, bangunan tahan gempa, rangka momen khusus dan metode respon spektrum.

\section{Pendahuluan}

Salah satu tahapan penting dalam perencanaan suatu struktur bangunan yaitu pemilihan jenis material yang akan digunakan. Selama ini material yang dikenal dalam dunia konstruksi berupa baja, beton bertulang serta kayu. Material baja sebagai bahan konstruksi telah lama digunakan mengingat baja memliki keunggulan dibandingkan material lain yaitu baja memiliki daktilitas yang cukup tinggi, karena suatu batang baja yang menerima tegangan tarik yang tinggi akan mengalami regangan tarik cukup besar sebelum terjadi keruntuhan.

Gempa bumi merupakan fenomena alam berupa getaran atau guncangan yang terjadi di permukaan bumi akibat adanya pelepasan energi dari kerak bumi secara tiba-tiba yang menciptakan gelombang seismik. Gempa bumi disebabkan oleh adanya pergerakan kerak bumi atau lempeng bumi. Lokasi terjadinya gesekan ini disebut fault zones. Benturan antar lempeng bumi tersebut menjalar dalam bentuk gelombang sehingga menyebabkan permukaan bumi dan bangunan di atasnya bergetar. Pada saat bergetar, timbul gaya-gaya pada struktur bangunan karena adanya kecenderungan massa bangunan untuk mempertahankan dirinya dari gerakan sehingga gempa bumi mempunyai kecenderungan menimbulkan gaya-gaya lateral pada struktur [1].

Dengan adanya beban lateral yang timbul akibat beban gempa, maka diperlukan analisa terkait untuk memperhitungkan besarnya pengaruh beban gempa tersebut terhadap struktur yang direncanakan sehingga struktur yang direncanakan mampu menahan beban gempa dan memenuhi filosofi bangunan tahan gempa.

Budiono dan Supriatna pada 2012 [2], memberikan filosofi dasar dalam merencanakan bangunan tahan gempa yaitu sebagai berikut :

a. Bila terjadi gempa ringan $(<4 \mathrm{SR})$, bangunan tidak boleh rusak. 
b. Bila terjadi gempa sedang (4 - 6 SR), bagian nonstruktural dari bangunan boleh rusak, tetapi bagian struktural dari bangunan tidak boleh rusak.

c. Bila terjadi gempa kuat ( $>6 \mathrm{SR}$ ), bangunan boleh rusak tetapi tidak langsung roboh, sehingga penghuni bangunan masih mempunyai waktu untuk menyelamatkan diri.

Dalam tulisan ini akan direncanakan bangunan struktur baja bertingkat tahan gempa dengan konfigurasi struktur sebagai struktur beraturan. Tujuannya agar dapat diperoleh suatu desain struktur baja tahan gempa sesuai dengan SNI 1729:2015 [3] dan SNI 1726:2012 [4] yang mengacu pada AISC-LRFD. Tujuan dari perencanan gedung struktur baja menurut SNI 1729:2015 [3] yaitu untuk menghasilkan suatu struktur gedung yang mampu berkinerja secara optimal pada kondisi beban kerja rencana serta memenuhi tujuan lainnya seperti kemudahan pelaksanaan. Pada umumnya suatu struktur dinyatakan layak apabila memenuhi persyaratan kekuatan dan kenyamanan dimana struktur tersebut tidak mudah terguling, miring atau tergeser selama umur rencana bangunan.

Dalam merencanakan suatu struktur tahan gempa terdapat beberapa hal yang harus diperhatikan sehubungan dengan pengaruhnya terhadap kinerja struktur dalam meneriman beban gempa. Secara garis besar, SNI 1726:2012 [4] memberikan 3 hal penting yang harus diperhatikan dalam perencanaan, yaitu :

a. Beban gempa rencana

Besarnya beban gempa rencana ditentukan oleh peruntukan bangunan, jumlah tingkat, berat total bangunan, dan lokasi bangunan tersebut didirikan (berkaitan dengan zona gempa). Selain itu, kondisi tanah di lokasi pembangunan gedung juga berpengaruh terhadap besaran beban gempa rencana.

b. Konfigurasi gedung

Konfigurasi gedung mempunyai pengaruh yang cukup signifikan terhadap perilaku struktur dalam menerima beban gempa. Bagian dari konfigurasi gedung yang paling berpengaruh ialah sifat geometrisnya, yang menentukan suatu struktur diklasifikasikan sebagai struktur beraturan atau tidak beraturan. Adapun syarat geometris dari suatu struktur gedung sesuai dengan SNI 1726:2012 [4] yaitu struktur gedung merupakan struktur beraturan yang memiliki denah simetris dalam horizontal maupun arah vertikal.

c. Daktilitas struktur

Daktilitas struktur merupakan suatu kemampuan suatu struktur untuk terus berdeformasi plastis saat menerima beban yang melampaui batas elastisnya. Daktilitas ini memungkinkan perencanaan gedung yang ekonomis, tapi tetap tidak runtuh mendadak saat terjadi gempa kuat.

Daktilitas struktur sangat bergantung kepada tipe sistem penahan gempa yang digunakan pada struktur tersebut. Karena setiap sistem penahan gempa memiliki tingkat deformasi yang beragam sesuai dengan prinsip kerjanya dan karakteristik material yang digunakan. Filosofi desain yang paling umum diterapkan dalam perancangan struktur tahan gempa yaitu konsep desain kapasitas. Konsep ini pada dasarnya bertujuan pada pengendalian terbentuknya sendi plastis terhadap elemen struktur tertentu dimana sendi plastis ini kemudian diharapkan mampu untuk memancarkan sekaligus membatasi energi gempa yang masuk ke sistem struktur melalui deformasi inelastis yang cukup besar tanpa mengalami keruntuhan sementara elemen struktur lainnya harus direncanakan agar lebih kuat dari sendi plastis yang terjadi [5].

Melalui mekanisme pemancaran energi ini, suatu struktur dapat didesain berdasarkan respon inelastisnya terhadap beban gempa. Oleh karena itu, perilaku daktail dari material struktur yang digunakan akan sangat menentukan bagi kemampuan struktur untuk dapat berdeformasi inelastik secara berkelanjutan akibat gempa tanpa mengalami penurunan kekuatan yang berarti [6-7].

Dalam penerapan konsep desain kapasitas struktur tahan gempa yaitu mekanisme pergoyangan struktur harus mengacu pada prinsip strong column weak beam dengan tujuan agar terjadi mekanisme pergoyangan dengan sebagian besar sendi plastis pada balok.

Adapun mekanisme kerja strong column weak beam yaitu pada saat struktur mendapat gaya lateral gempa, distribusi kerusakan sepanjang ketinggian bangunan bergantung pada distribusi lateral story drift (simpangan antar lantai). Jika struktur memiliki kolom lebih kuat daripada balok (strong column weak beam), maka drift akan tersebar merata dan keruntuhan lokal di satu lantai dapat diminimalkan (Gambar 1a). Sebaliknya jika kolom yang lemah, simpangan antar lantai akan cenderung terpusat pada satu lantai (soft story effect) seperti ditunjukkan pada Gambar 1b.

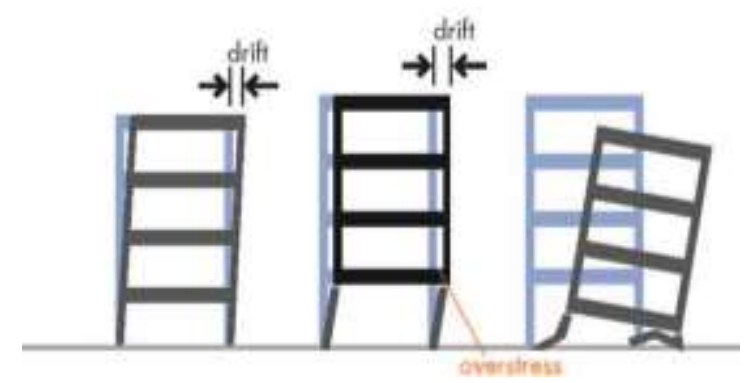

a. Strong column weak beam b. soft story effect

Gambar 1. Mekanisme keruntuhan soft story [8]

Untuk menghitung besarnya pengaruh beban gempa terhadap suatu struktur gedung digunakan analisis ragam spektrum respon yang merupakan metode analisis respon dinamik yang diperoleh dari hasil superposisi respon dinamik maksimum oleh sejumlah ragam getarnya (mode shape). Metode ini juga merupakan metode analisis dinamik yang bersifat linier-elastik dimana spektrum respon yang digunakan dalam analisis merupakan hasil idealisasi atau penyederhanaan dari spektrum respon linier-elastik (linier elastic response spectrum), yang berupa grafik hubungan antara spektrum percepatan gempa dan periode getar seperti pada Gambar 2.

Gambar 2 memperlihatkan salah satu contoh dari spektrum respon asli yang berupa akselelogram yang sangat fluktuatif hasil rekaman gempa San Fransisco pada tahun 1971. Rekaman akselelogram tersebut kemudian diberikan 
redaman kritis (critical damping) sebesar 2\%, 5\%, 10\%, dan $20 \%$, untuk memperoleh spektrum rata-rata yang dapat mewakili banyak spektrum pada periode T tertentu. Dalam hal ini spektrum rata-rata diperoleh pada redaman sebesar 5\%. Kemudian spektrum respon rata-rata tersebut dibuat menjadi lebih halus (smoothed elastic spectrum), seperti Gambar 3.

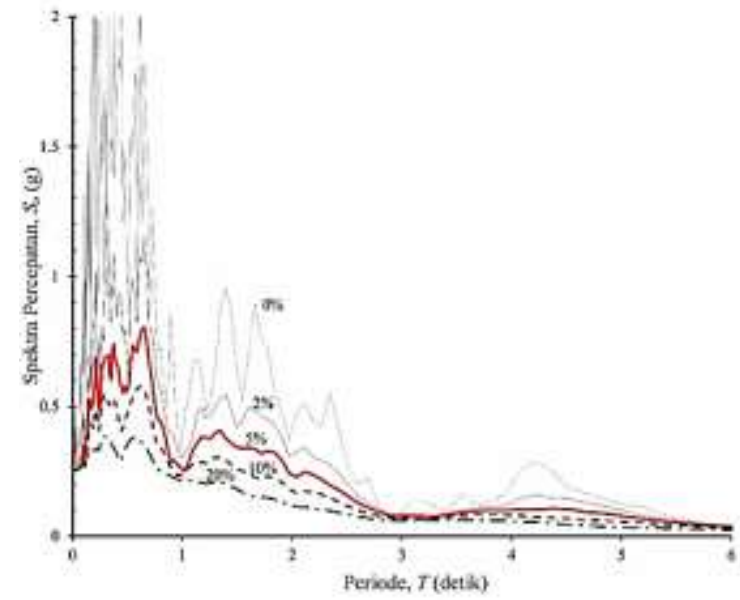

Gambar 2. Spektrum respon gempa San Fernando 1971 dengan berbagai tingkat redaman [9].

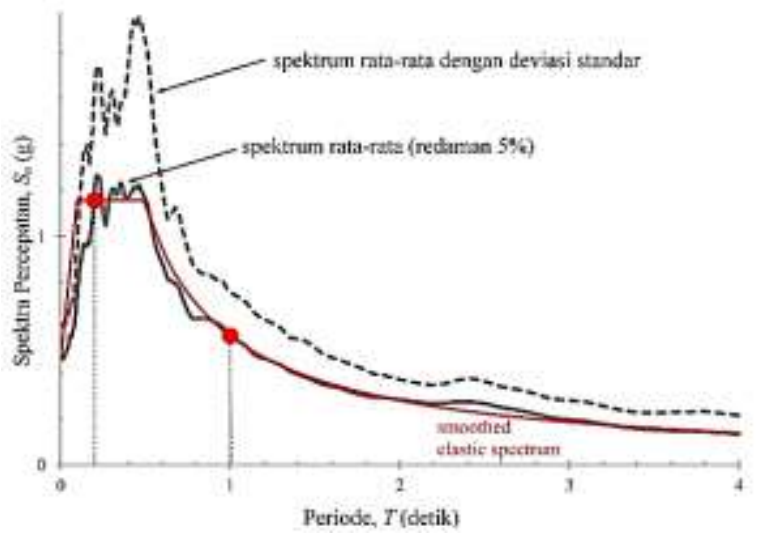

Gambar 3. Spektrum respon rata-rata dan smoothed elastic spectrum [9]

Smoothed elastic spectrum merupakan spektrum respon elastik yang telah disederhanakan namun masih harus diproses lebih lanjut lagi untuk mendapatkan spektrum respon inelastik. Spektrum respon inelastik inilah yang nantinya akan dipakai untuk menghitung beban gempa desain, sesuai dengan daktilitas sistem struktur yang direncanakan. Untuk mengubah spektrum respon elastik menjadi spektrum respon inelastik maka diperlukan suatu faktor skala yang merupakan perbandingan antara faktor keutamaan gempa $I_{e}$ dan koesifien modifikasi respon $R$ yang merupakan representasi dari daktilitas sistem struktur yang direncanakan.

Gambar 4 memperlihatkan spektrum respon elastik yang telah diskalakan menjadi spektrum respon inelastik. Untuk mendapatkan hasil kombinasi dari respon masing-masing ragam dapat menggunakan 2 metode kombinasi yaitu kombinasi kuadratik lengkap (CQC) dan akar jumlah kuadrat (SRSS), tentunya dengan sejumlah syarat yang harus diperhatikan dalam penggunaan salah satu dari metode di atas.
Dalam mendesain elemen struktur baja terhadap pengaruh beban gempa dan beban lainnya yang bekerja pada struktur, digunakan metode LRFD (Load Resistance Factor Design). Metode LRFD merupakan metode perencanaan struktur baja dengan membandingkan kekuatan struktur yang diberi suatu faktor resistensi $(\phi)$ terhadap kombinasi beban terfaktor yang bekerja pada struktur tersebut ( $\sum \gamma$ iQi). Pada metode ini fokus perencanaan berdasarkan kondisi batas kekuatan (ultimate strength) yang menjamin keselamatan publik terhadap beban ekstrim selama masa pakai struktur.

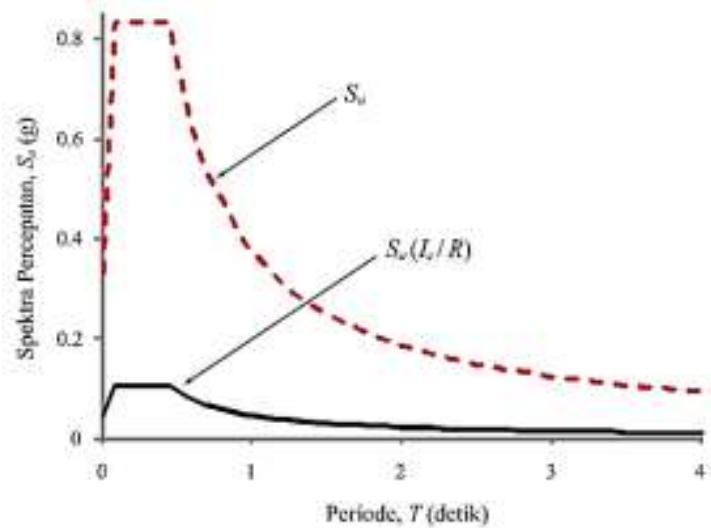

Gambar 4. Spektrum respon elastik yang diskalakan [9]

Perencanaan metode LRFD memenuhi syarat jika kuat rencana $\phi R n$ lebih besar dari kuat perlu $\mathrm{Ru}$ dengan nilai $\phi$ bervariasi tergantung aksi komponen yang ditinjau [10]. Kuat perlu merupakan nilai maksimum dari berbagai kombinasi pembebanan yang ditentukan dengan bantuan analisis struktur. Hasil analisis struktur kemudian digunakan untuk mengevaluasi setiap elemen struktur dan dibandingkan dengan kuat rencana tiap elemen struktur sesuai dengan gaya internal yang bekerja. Tinjauan setiap elemen diperlukan dengan tujuan untuk memeriksa karakter setiap aksi dan perilaku keruntuhannya.

\section{Metode Penelitian}

\subsection{Data Perencanaan}

Lokasi perencanaan gedung dalam tulisan ini terletak di Kota Palu, Sulawesi Tengah. Pemilihan lokasi ini dimaksudkan karena Kota Palu merupakan salah satu wilayah gempa kuat sesuai dengan Peta Hazard Gempa Indonesia 2017 [11].

Gedung direncanakan merupakan gedung perkantoran bertingkat 5 (lima) dengan tinggi tipikal 3,8 meter. Sistem struktur atas yang digunakan merupakan Sistem Rangka Pemikul Momen Khusus (SRPMK) dari baja [12-16]. Pemilihan dimensi profil yang akan digunakan dalam perencanaan yaitu dengan cara memperkirakan (trial error) dimensi awal elemen struktur berdasarkan ketentuan yang berlaku. Sistem lantai digunakan struktur komposit dengan dek baja gelombang. Adapun tipe struktur bawah digunakan pondasi tiang beton (bored pile).

Material struktur yang digunakan terdiri dari baja dengan mutu A36 (fy $=250 \mathrm{MPa}$; fu $=400 \mathrm{MPa}$ ) dan beton dengan kuat tekan f'c $=30 \mathrm{MPa}$. Denah gedung arah horizontal memiliki bentang yang bervariasi yaitu $4 \mathrm{~m}$ dan 
$6 \mathrm{~m}$. Sedangkan denah gedung arah vertikal diseragamkan dengan bentang $5 \mathrm{~m}$. Adapun denah dari struktur yang direncanakan seperti Gambar 5.

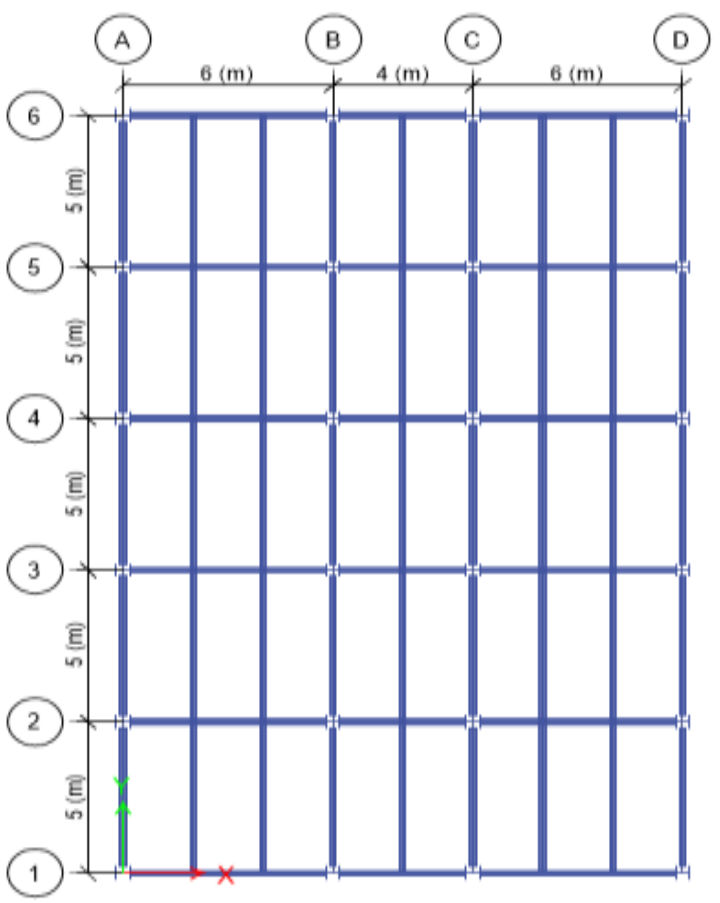

Gambar 5. Denah rencana gedung

\subsection{Metode Perencanaan}

Perencanaan awal (Preliminary design) dan pemodelan struktur, Perhitungan beban gravitasi dan beban gempa berdasarkan SNI 1727-2013 [17] dan SNI 1726-2012 [4] berurutan. Selanjutnya dilakukan perhitungan kombinasi pembabanan dan analisa struktur dengan bantuan Etabs 16 [18]. Kemudian pengecekan waktu getar alami struktur (T). rasio partisipasi massa gaya geser dasar (base shear) dan evaluasi kinerja struktur yakni simpangan antar lantai dan efek P-delta. Jika semuanya memenuhi maka dilanjutkan dengan desain elemen struktur berdasarkan SNI 1727-2015 [3] dan desain sambunga, namun jika hasilnya tidak memenuhi maka kembali ke perencanaan awal

\section{Hasil dan Pembahasan}

\subsection{Dimensi Elemen Struktur}

Tabel 1 merupakan dimensi awal elemen struktur yang digunakan dalam perencanaan didasarkan pada preliminary design dengan memperkirakan profil yang digunakan sesuai ketentuan yang berlaku.

Tabel 1. Dimensi elemen struktur

\begin{tabular}{|c|c|c|}
\hline $\begin{array}{l}\text { Elemen } \\
\text { Struktur }\end{array}$ & Dimensi & Keterangan \\
\hline \multirow{3}{*}{ Balok } & W16 x $7 \times 40$ & $\begin{array}{c}\text { Balok Induk arah X } \\
\text { Tkt } 1-5\end{array}$ \\
\hline & W14 x $6,75 \times 38$ & $\begin{array}{c}\text { Balok Induk arah Y } \\
\text { Tkt } 1-5 \\
\end{array}$ \\
\hline & W8 $\times 6,5 \times 24$ & $\begin{array}{c}\text { Balok Anak Tkt } 1- \\
5\end{array}$ \\
\hline Kolom & W14 x $16 \times 211$ & Seragam \\
\hline Pelat & $120 \mathrm{~mm}$ (tebal) & Seragam \\
\hline
\end{tabular}

\subsection{Pemodelan Struktur 3 Dimensi}

Sebagaimana telah dituliskan sebelumnya bahwa Berdasarkan dimensi elemen struktur yang direncanakan, kemudian struktur gedung dimodelkan ke dalam bentuk 3D menggunakan Etabs 2016. Berikut hasil pemodelan struktur gedung menggunakan perangkat lunak Etabs 2016 diperlihatkan oleh Gambar 6.

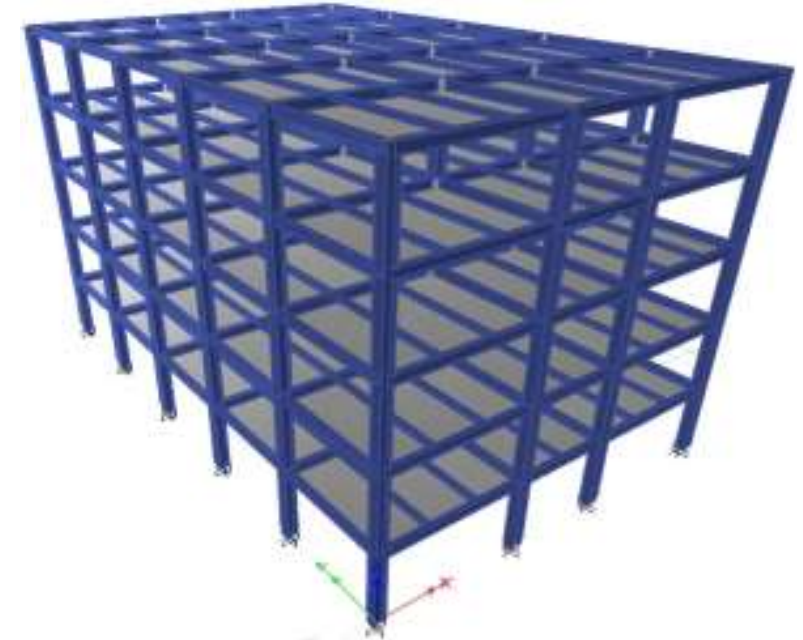

Gambar 6. Tampilan perspektif struktur

\subsection{Pembebanan Struktur}

Secara garis besar beban yang bekerja pada struktur terbagi atas beban gravitasi, beban notional dan beban gempa. Beban gravitasi merupakan seluruh beban mati $(D)$ dan beban hidup $(L)$ yang direncanakan bekerja pada struktur yang terdiri dari

a. Beban mati $(D)$

- Berat sendiri elemen struktur (dihitung secara otomatis oleh program Etabs 2016)

- Beban finishing pelat atap, $Q=1,913 \mathrm{kN} / \mathrm{m}^{2}$

- Beban finishing pelat lantai, $Q=1,397 \mathrm{kN} / \mathrm{m}^{2}$

- Beban dinding partisi kaca :

- $\quad q=2,102 \mathrm{kN} / \mathrm{m}(\operatorname{arah} \mathrm{x})$

- $\quad q=2,117 \mathrm{kN} / \mathrm{m}$ (arah y)

- Beban dinding partisi bata ringan :

- $q=7,065 \mathrm{kN} / \mathrm{m}(\operatorname{arah} \mathrm{x})$

- $q=7,167 \mathrm{kN} / \mathrm{m}$ (arah y)

b. Beban hidup $(L)$

- Beban hidup merata pada pelat atap, $Q=0,96 \mathrm{kN} / \mathrm{m}^{2}$

- Beban hidup merata pada pelat lantai :

- $\quad$ Lobi dan koridor lantai pertama $=4,79 \mathrm{kN} / \mathrm{m}^{2}$

- Koridor di atas lantai pertama $=3,83 \mathrm{kN} / \mathrm{m}^{2}$

- $\quad$ Kantor $=2,40 \mathrm{kN} / \mathrm{m}^{2}$

Sementara itu, untuk beban notional yang bekerja pada struktur akan dihitung secara otomatis oleh program Etabs 2016 dengan besar beban yang bekerja yaitu 0,002 dari berat total struktur. Untuk beban gempa, dianalisis menggunakan metode respon spectrum (analisis ragam spectrum respon), dengan parameter analisisnya ditentukan berdasarkan SNI 1726:2012 (Tabel 2):

- Jenis pemanfaatan gedung : Kantor

- Kategori resiko struktur: II

- Faktor keutamaan gempa, $I_{e}=1,0$ 
Tabel 2. Kombinasi Beban

\begin{tabular}{l}
\hline \multicolumn{1}{c}{ Kombinasi beban } \\
\hline $1,4 D$ \\
\hline $1,2 D+1,6 L$ \\
\hline $1,2 D+1,0 N+1,0 L$ \\
\hline $1,2 D-1,0 N+1,0 L$ \\
\hline $0,9 D+1,0 N$ \\
\hline $1,46 D+1,3 Q_{x}+0,39 Q_{y}+0,5 L$ \\
\hline $1,46 D+0,39 Q_{x}+1,3 Q_{y}+0,5 L$ \\
\hline $0,64 D+1,3 Q_{x}+0,39 Q_{y}$ \\
\hline $0,64 D+0,39 Q_{x}+1,3 Q_{y}$ \\
\hline$D \quad:$ Beban mati \\
$L \quad:$ Beban hidup \\
$Q_{x} \quad:$ Beban gempa arah sumbu x \\
$Q_{y} \quad:$ Beban gempa arah sumbu y \\
\hline
\end{tabular}

- Nilai $\mathrm{S}_{\mathrm{s}}=2,164 \mathrm{~g}$

- Nilai $\mathrm{S}_{1}=0,765 \mathrm{~g}$

- Faktor $\mathrm{F}_{\mathrm{a}}=0,90$

- Faktor $F_{v}=2,40$

- Respon percepatan gempa desain :

$-\mathrm{S}_{\mathrm{DS}}=1,298 \mathrm{~g} ; \mathrm{S}_{\mathrm{D} 1}=1,224 \mathrm{~g}$

- Periode $\mathrm{T}_{\mathrm{S}}=0,943$ detik

- Periode $\mathrm{T}_{0}=0,189$ detik

- Kategori desain seismik : E

- Faktor daktilitas struktur, $\mathrm{R}=8$

\subsection{Hasil Analisa Struktur}

Dari hasil analisis struktur menggunakan bantuan perangkat lunak (software) Etabs 2016, diperoleh bentuk ragam getar (mode shape) pertama dan kedua struktur ketika dilakukan analisa vibrasi beban yaitu didominasi oleh gerak translasi untuk masing-masing arah sumbu-X dan sumbu-Y. Bentuk kedua ragam getar yang dimaksud dapat dilihat seperti pada Gambar 8 dan Gambar 9.

- Klasifikasi situs : Tanah lunak, SE

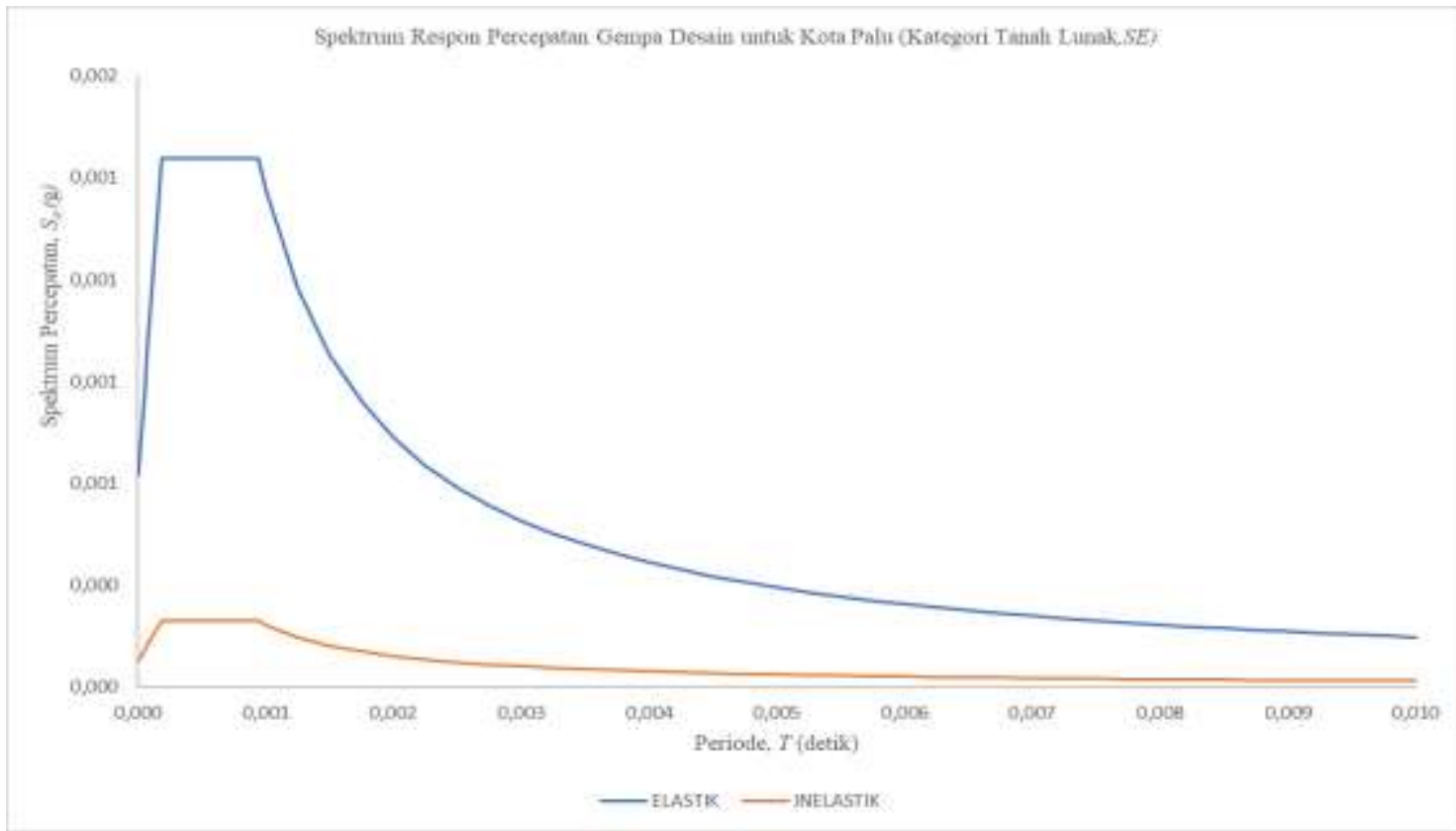

Gambar 7. Spektrum Respon Percepatan Gempa Desain

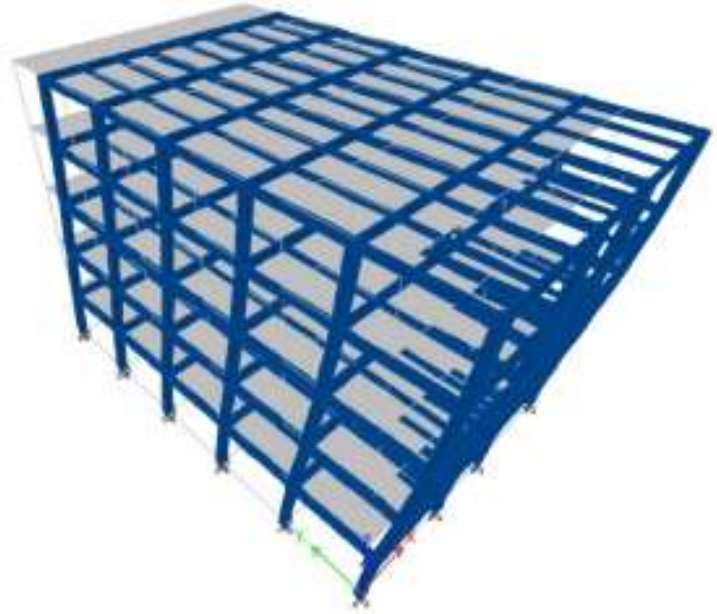

Gambar 8. Ragam Getar Pertama $(T=1,121$ detik)

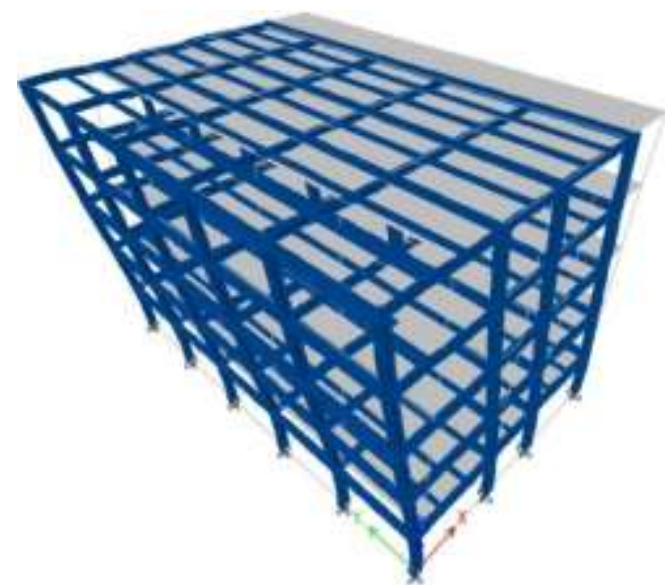

Gambar 9. Ragam Getar Kedua $T=0,934$ detik) 
Sementara itu, nilai rasio partisipasi massa yang diperoleh dari 15 ragam getar yang diikutsertakan dalam analisis, mencapai $90 \%$ pada ragam getar ke-5 dengan ragam pertama dan kedua di dominasi oleh gerak translasi. Waktu getar alami yang dimiliki struktur pada arah sumbuX sebesar $T=0,934$ detik. Nilai periode ini memenuhi batas atas periode fundamental $C_{u} T_{a}$ dan periode fundamental pendekatan $T_{a}$, hal ini sesuai persyaratan waktu getar alai struktur yang diatur dalam SNI 1726:2012 [4]. Sedangkan waktu getar alami yang dimiliki struktur pada arah sumbuY sebesar $T=1,121$ detik, dimana nilai periode tersebut melebihi batas atas periode fundamental $C_{u} T_{a}$ dan memenuhi batas periode fundamental pendekatan $T_{a}$, sehingga untuk memenuhi syarat waktu getar alami, maka digunakan batas atas periode fundamental sebagau waktu getar struktur pada arah-Y.

Simpangan antar lantai yang terjadi pada struktur menunjukkan bahwa seluruh simpangan yang terjadi masih dalam batas aman, yang artinya bahwa keseluruhan kinerja struktur gedung yang direncanakan sudah cukup baik. Simpangan antar lantai terbesar terjadi pada arah sumbu Y, yaitu di tingkat 2 sebesar 93,5 mm. Nilai simpangan ini kurang dari simpangan antar lantai ijin sebesar $95 \mathrm{~mm}$. Adapun lebih jelasnya dapat dilihat pada Gambar 10.

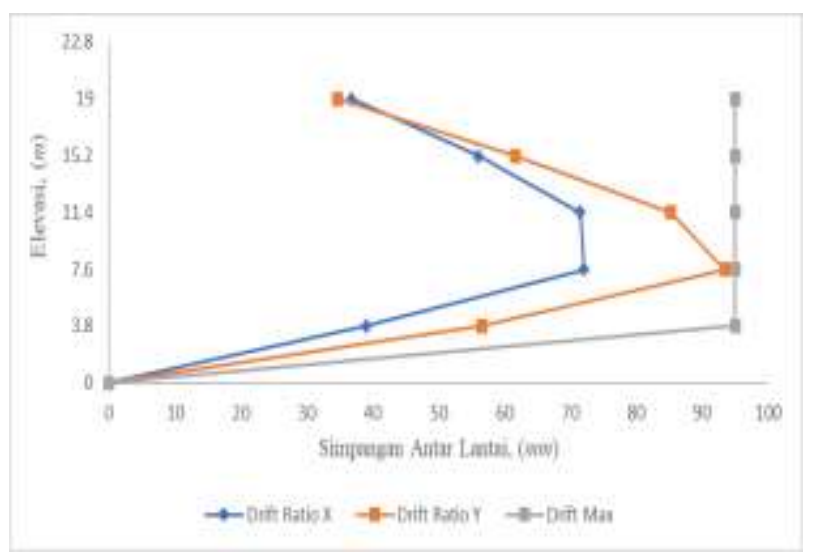

Gambar 10. Grafik Simpangan Antar Lantai

Hasil analisis diatas menunjukkan bahwa baik dimensi maupun geometri dari struktur yang direncanakan sudah cukup untuk menjamin struktur tetap berperilaku elastis selama terjadi gempa, terlepas dari daktilitas yang direncanakan pada struktur tersebut.

\subsection{Hasil Desain Elemen Struktur}

Berikut merupakan hasil desain elemen struktur untuk gedung yang direncanakan:

a. Balok

Profil balok yang digunakan pada struktur yang direncanakan termasuk penampang kompak sehingga tekuk lokal tidak akan terjadi pada balok sehingga kuat lentur nominal penampang hanya bergantung pada kondisi batas material leleh (yielding) atau kondisi batas tekuk lateral. Adapun juga profil balok yang digunakan memenuhi syarat kekuatan dimana kuat lentur dan kuat geser nominal profil yang digunakan mampu menahan momen dan geser akibat beban yang bekerja pada struktur.
Adapun jenis sambungan yang digunakan pada balok yaitu sambungan reduced beam section (RBS) untuk balok pada arah sumbu X dan sambungan flush end plate untuk balok pada arah sumbu Y. Masing-masing dari kedua jenis sambungan yang digunakan pada balok memenuhi syarat yang berlaku.

b. Kolom

Profil kolom yang digunakan pada struktur yang direncanakan termasuk penampang kompak sehingga tekuk lokal tidak akan terjadi pada balok sehingga kuat lentur nominal penampang hanya bergantung pada kondisi batas material leleh (yielding) atau kondisi batas tekuk lateral.

Profil kolom yang "kompak" juga berdampak pada tidak terjadinya pembesaran momen akibat P-Delta sehingga kolom yang digunakan mampu menahan beban yang bekerja pada struktur dan memenuhi syarat kekuatan dimana kuat lentur dan kuat tekan nominal profil yang digunakan mampu menahan momen dan gaya aksial akibat beban yang bekerja pada struktur. Adapun profil kolom yang digunakan juga memenuhi syarat pada pasal H1 SNI 1729:2015 terkait struktur elemen yang menerima kombinasi gaya aksial dan momen sekaligus.

c. Join

Pada pertemuan antara balok dengan kolom (join) tidak perlu adanya penambahan pelat ganda untuk menambah kekuatan geser pada join. Hal ini sesuai dengan Pasal J10-11 ANSI/AISC 360-10 dimana jika kuar geser nominal pada join lebih dari geser yang terjadi pada join $\left(\phi R_{v}>R_{u}\right)$, maka tidak diperlukan pelat ganda (doubler plate) pada join.

Adapun dari hasil pemeriksaan kuat lentur nominal balok dan kolom yang bertemu d join menunjukkan bahwa kuat lentur nominal kolom hasil desain lebih besar daripada kuat lentur nominal balok yang bertemu di join yang sama di semua tingkatan struktur. Hal ini juga memberikan gambaran bahwa daktilitas yang dimilik struktur gedung hasil perencanaan telah memenuhi konsep "kolom kuat-balok lemah".

d. Pelat

Pelat yang digunakan berupa pelat komposit antara beton dengan dek baja gelombang. Dengan mutu beton $30 \mathrm{MPa}$ serta kuat leleh dek baja $350 \mathrm{MPa}$, mampu menahan beban yang bekerja pada pelat selama masa konstruksi dan setelah masa konstruksi. Adapun beton dan dek baja dihubungkan menggunakan shear connector tipe stud dengan diameter $19 \mathrm{~mm}$ dengan jumlah stud connector sebanyak 19 buah.

\section{Kesimpulan}

Berdasarkan hasil analisis dan desain struktur yang telah dilakukan, terdapat beberapa kesimpulan yang dapat diambil dari penulisan ini.

1). Berdasarkan analisis modal terhadap model struktur gedung rencana memiliki potensi terhadap terjadinya efek torsi akibat beban gempa. Hal ini dapat dilihat dari nilai rasio partisipasi massa (ragam pertama) akibat 
gerak rotasi pada arah sumbu X sebesar 19,81\% lebih besar dari gerak translasi pada arah sumbu tersebut.

2). Struktur gedung yang direncanakan memiliki karakteristik dinamik sebagai berikut

a. Periode fundamental struktur untuk ragam pertama saat dilakukan analisis vibrasi bebas ialah 1,121 detik, nilai ini memenuhi syarat batas bawah periode getar struktur namun melewati batas atas periode getar struktur sehingga digunakan batas atas periode getar (1,069 detik) untuk periode fundamental ragam pertama dan telah memenuhi syarat dalam SNI 1726:2012.

b. Periode fundamental struktur untuk ragam kedua saat dilakukan analisis vibrasi bebas ialah 0,934 detik, nilai ini memenuhi syarat batas bawah dan batas atas periode getar struktur sesuai dalam SNI 1726:2012.

c. Simpangan antar lantai maksimum struktur terjadi pada tingkat 2, dengan nilai simpangan sebesar 93,5 $\mathrm{mm}$ yang memenuhi syarat kurang dari nilai simpangan antar lantai ijin sebesar $95 \mathrm{~mm}$. Hal ini memberikan gambaran bahwa struktur yang direncanakan tahan gempa memiliki standar kerja yang cukup baik sesuai dengan SNI 1726:2012.

d. Daktilitas yang dimiliki struktur dari hasil perencanaan telah sesuai dengan prinsip strong column weak beam. Hal ini dibuktikan dengan kuat lentur nominal kolom hasil desain yang lebih besar dari kuat lentur nominal balok yang bertemu pada join yang sama di semua tingkat.

3). Dalam perencanaan sistem rangka pemikul momen khusus (SRPMK) pada struktur yang direncanakan memenuhi syarat kapasitas yang sesuai dengan SNI 1729:2015 dan AISC 358-10. Adapun hasil desain terhadap tiap-tiap elemen struktur tersebut adalah sebagai berikut :

a. Elemen balok pada struktur dalam sumbu X memiliki dimensi yang seragam, yaitu profil W16x7 40 pada semua tingkat dengan sambungan menggunakan sambungan reduced beam section. Sedangkan elemen balok pada struktur dalam sumbu Y juga memiliki dimensi yang seragam, yaitu profil $\mathrm{W} 14 \times 6,75 \times 38$ pada semua tingkat dengan sambungan menggunakan sambungan flush end plate.

b. Sambungan reduced beam section dengan kedalaman coakan (parameter c) 35,6 mm menghasilkan momen maksimum pada muka kolom $\left(M_{f}=372,549\right.$ kN.m) kurang dari momen plastis pada balok $\left(\phi_{d} M_{p e}=401,25 \mathrm{kN} . \mathrm{m}\right)$.

c. Untuk sambungan flush end plate diperoleh tebal pelat ujung $26 \mathrm{~mm}$ serta diameter baut yang digunakan $24 \mathrm{~mm}$ dengan jumlah baut pada sisi tarik sebanyak 4 buah dan jumlah baut pada sisi desak sebanyak 2 buah.

d. Elemen kolom pada struktur di semua tingkat memiliki dimensi yang seragam, yaitu profil $\mathrm{W} 14 \times 16 \times 211$. Elemen kolom mampu menahan momen akibat sambungan terhadap balok yang dibuktikan dengan tidak diperlukan pelat menerus pada pertemuan antar balok dengan kolom (join).

e. Pertemuan antar balok dengan kolom (join) memiliki kuat geser yang lebih besar dari gaya geser pada join yang dihasilkan. Hal ini dibuktikan dengan tidak diperlukan pelat ganda (doubler plate) pada zona panel.

4). Elemen pelat yang didesain dengan ketebalan $120 \mathrm{~mm}$ menggunakan dek gelombang mampu menahan momen yang terjadi pada masa konstruksi (sebelum komposit) dan masa layan (setelah komposit). Beton dan dek baja dihubungkan menggunakan shear connector tipe stud dengan diameter $19 \mathrm{~mm}$ dengan jumlah stud connector sebanyak 19 buah.

5). Dimensi yang digunakan untuk base plate pada kolom eksterior dan kolom interior yait $600 \mathrm{~mm}$ x $600 \mathrm{~mm}$ dengan ketebalan $55 \mathrm{~mm}$. Adapun baut angkur pada base plate kolom eksterior berjumlah 10 buah dan 4 buah baut angkur pada base plate kolom interior. Berdasarkan hasil perhitungan, diperoleh bahwa baut angkur mampu menahan interaksi antara gaya tarik dan gaya geser yang terjadi pada baut angkur.

\section{Daftar Pustaka}

[1] D.L. Schodek, Struktur, Bandung: PT. ERESCO, 1991.

[2] Budiono and Supriatna, Studi Komparasi Desain Bangunan Tahan Gempa, Bandung: ITB, 2012.

[3] BSN, SNI 1727-2015: Spesifikasi Untuk Bangunan Gedung Baja Struktural, Jakarta: Badan Standarisasi Nasional, 2015.

[4] BSN, SNI 1726: Tata Cara Perencanaan Ketahanan Gempa untuk Struktur Bangunan Gedung dan NonGedung, Jakarta: Badan Standarisasi Nasional, 2012.

[5] R.W. Clough and J. Penzien, Dynamics of Structures Berkeley: Computers \& Structures, Inc., 1995.

[6] K. Muto, Analisis Perancangan Gedung Tahan Gempa, Jakarta: Erlangga, 1993.

[7] T. Paulay and M. Priestley, Seismic Design of Reinforced Concrete and Masonry Buildings, New York: John Wiley \& Sons, Inc., 1992.

[8] FEMA, NEHRP Recomended Provisions for New Building and Other Structures: Training and Instructions Materials (FEMA 451b), Washington: Federal Emergency Management Agency: 2007.

[9] FEMA, Recomended Seismic Provisions: Design Examples (FEMA P-751), Washington: Federation Emergency Management Agency NEHRP, 2012.

[10] A. Setiawan, Perencanaan Struktur Baja Dengan Metode LRFD. Jakarta: Erlangga, 2008.

[11] Kementerian-PUPR, Peta Sumber dan Bahaya Gempa Indonesia, Jakarta: Kementerian Pekerjaan Umum dan Perumahan Rakyat, 2017. 
[12] W. Dewobroto, Komputer Rekayasa Struktur dengan SAP2000, Jakarta: LUMINA Press dan Dapur Buku, 2013.

[13] W. Dewobroto, Rekayasa Komputer Dalam Analisis dan Desain Struktur Baja, Studi Kasus Direct Analysis Method (AISC 2010), Semarang: Universitas Kristen Petra, 2014.

[14] W. Dewobroto, Struktur Baja Perilaku, Analisis \& Desain-AISC 2010, Jakarta: LUMINA Press, 2016.

[15] AISC, Specification for The Design, Fabrication and Erection of Structural Steel for Buildings, Chicago: American Institute Of Steel Contruction, 1978.
[16] AISC, Manual of Steel Construction, Load \& Resistance Factor Design, 2nd Edition,Volume 2, Illinois: American Institute of Steel Contruction, 1994.

[17] BSN, SNI 1727:2013, Beban Minimum untuk Perancangan Bangunan Gedung dan Struktur Lain, Jakarta: Badan Standarisasi Nasional, 2013.

[18] Computers-and-Structures, Steel Frame Design Manual AISC 360-10 for Etabs, USA: Computers \& Structures INC., 2016. 